\title{
Antiproliferative effect of natural tetrasulfides in human breast cancer cells is mediated through the inhibition of the cell division cycle 25 phosphatases
}

\author{
ELODIE VIRY $^{1}$, AWAIS ANWAR ${ }^{2}$, GILBERT KIRSCH $^{1}$, CLAUS JACOB $^{2}$, \\ MARC DIEDERICH $^{3}$ and DENYSE BAGREL ${ }^{1}$
}

${ }^{1}$ Laboratoire d'Ingénierie Moléculaire et Biochimie Pharmacologique, EA 3940, FR CNRS 2843, UFR SciFA, Rue du Général Delestraint, 57070 Metz, France; ${ }^{2}$ School of Pharmacy, Saarland University

(Universität des Saarlandes), D-66041 Saarbruecken, Germany; ${ }^{3}$ Laboratoire de Biologie Moléculaire et Cellulaire du Cancer, Fondation de Recherche Cancer et Sang, Hôpital Kirchberg, L-2540 Luxembourg, Luxembourg

Received June 7, 2010; Accepted July 26, 2010

DOI: 10.3892/ijo.2011.913

\begin{abstract}
For many years, in vitro and in vivo studies have reported that organosulfur compounds (OSCs), naturally found in Allium vegetables, are able to suppress the proliferation of various tumor cells. In spite of recent advances, the specific molecular mechanisms involved in OSC activity are still unclear. Considering the antiproliferative effects observed in cancer cells, we postulated that OSCs might target the cell division cycle $(\mathrm{Cdc}) 25$ phosphatases which are crucial enzymes of the cell cycle. Our findings suggest phosphatases Cdc25 as possible targets of naturally occuring polysulfides contributing to their anticancer properties. We report on the inhibitory activity of tetrasulfides occurring naturally in garlic and onion towards the human $\mathrm{Cdc} 25$ phosphatases. Diallyl- and dipropyltetrasulfides have emerged as interesting irreversible inhibitors of the $\mathrm{Cdc} 25$ isoforms A and $\mathrm{C}$ in vitro. Furthermore, growth of both sensitive (MCF-7) and resistant (Vcr-R) human breast carcinoma cells was significantly decreased by these tetrasulfides. The observed antiproliferative effect appeared to be associated with a $\mathrm{G}_{2}-\mathrm{M}$ cell cycle arrest.
\end{abstract}

\section{Introduction}

For many centuries, Allium vegetables, such as garlic and onion, have been used to prevent a large variety of health disorders. Several epidemiologic studies have supported the

Correspondence to: Professor Denyse Bagrel, Laboratoire d'Ingénierie Moléculaire et Biochimie Pharmacologique, FR CNRS 2843, Université Paul Verlaine-Metz, Rue du Général Delestraint, 57070 Metz, France

E-mail: bagrel@univ-metz.fr

Key words: breast cancer, Cdc25 inhibition, $\mathrm{G}_{2}-\mathrm{M}$ arrest, organic tetrasulfides current inverse correlation between dietary intake of Allium vegetables and cancer risk (1-3). These anticarcinogenic properties were described to be due to biologically active sulfur compounds found in Allium vegetables. Amongst them, allicin plays a crucial role in garlic chemistry because its degradation results in the production of various organic sulfur compounds, such as the well-known diallylmonosulfide (DAS), -disulfide $\left(\mathrm{DAS}_{2}\right)$ and -trisulfide $\left(\mathrm{DAS}_{3}\right)$ (reviewed in ref. 4). These diallylsulfides have been shown to offer protection against cancer induced by chemical agents in animal models (5). In addition, sulfur compounds are able to suppress the proliferation of various types of cultured cancer cells by inducing apoptosis and/or cell cycle blockage. For example, recent studies revealed that these compounds inhibit the growth of human prostate and colon cancer cells in association with $\mathrm{G}_{2}-\mathrm{M}$ phase cell cycle arrest $(6,7)$. Interestingly, studies performed in vitro and in vivo showed that sulfides could selectively target the tumor cells without affecting significantly healthy cells $(7,8)$. In spite of recent advances made in the understanding of anticancer effects of organic sulfur compounds, the specific molecular mechanisms involved in their activity are still not clearly elucidated.

The cell division cycle (Cdc) 25 dual-specificity phosphatases are important regulators of eukaryotic cell cycle progression. Three members of the Cdc25 family exist in humans, all of which feature an active site cysteine residue. They play a crucial role in the activation of cyclin-dependent kinases (Cdk) by dephosphorylating the phospho-Thr14 and phosphoTyr15 residues (reviewed in ref. 9). Cdc25 A appears to be mainly implicated in the progression to the $\mathrm{S}$ phase while $\mathrm{Cdc} 25 \mathrm{~B}$ and $\mathrm{C}$ are known to be required specifically for entry into mitosis. However, the three $\mathrm{Cdc} 25$ isoforms are able to control $\mathrm{G}_{1}-\mathrm{S}$ and $\mathrm{G}_{2}-\mathrm{M}$ transition by activating $\mathrm{Cdk} 1$ and Cdk2, respectively (10). Over-expression of Cdc25 A and $\mathrm{B}$ was reported in various types of human malignancies including breast cancer (9). Moreover, Cdc25 over-expression has been correlated with either poor prognosis or tumor aggressiveness (11). Taken together, these data suggest that Cdc25 enzymes are attractive targets in cancer therapy. 
Considering the antiproliferative effects induced by organic sulfur compounds in cancer cells, the ability of polysulfides to modify cysteine residues in proteins and enzymes and the crucial role of $\mathrm{Cdc} 25$ phosphatases in cell cycle progression, we postulated that these enzymes might be potential targets of such compounds. The direct inhibition of Cdc25 activity by polysulfides found in garlic and onion is reported herein for the first time. The most potent in vitro $\mathrm{Cdc} 25$ inhibitors, diallyltetrasulfide $\left(\mathrm{DAS}_{4}\right)$ and dipropyltetrasulfide $\left(\mathrm{DPS}_{4}\right)$, are able to prevent breast cancer cell proliferation through a cell cycle arrest in $\mathrm{G}_{2}-\mathrm{M}$.

\section{Materials and methods}

Synthesis of organosulfur compounds. Organosulfur compounds were obtained from the Jacob Group. Diallylsulfide and diallyldisulfide were purchased from Sigma (Bornem, Belgium) and distilled before use. Diallyltrisulfide was synthesized according to the method of Milligan et al (12) and purified by vacuum distillation; diallyltetrasulfide was synthesized following the method of Derbesy and Harpp (13) and purified by column chromatography. Identity and purity of the compounds were confirmed by GC-MS, ${ }^{1} \mathrm{H}-\mathrm{NMR},{ }^{13} \mathrm{C}$ NMR or GC-MS and HPLC, respectively. Pure oils were stored at $-80^{\circ} \mathrm{C}$ and dissolved in DMSO immediately before use and kept throughout the experiment. The propylanalogues were synthesized and purified according to the procedures employed for the allyl-compounds, with one minor difference: propylbromide was used instead of propylchloride for the synthesis of dipropyltrisulfide while propyl mercaptane was used instead of allyl mercaptane for the synthesis of dipropyltetrasulfide. Analytical data obtained for the dipropylsulfides were in accordance with the literature.

Cell culture. The human mammary adenocarcinoma cell line MCF-7 (ECACC, UK) and its counterpart resistant to vincristine Vcr-R (14) were used in this study. The cells were cultured in RPMI-1640 medium (Eurobio, France) supplemented with $10 \%(\mathrm{v} / \mathrm{v})$ fetal bovine serum and penicillin $(100 \mathrm{UI} / \mathrm{ml}) /$ streptomycin $(100 \mu \mathrm{g} / \mathrm{ml})$ at $37^{\circ} \mathrm{C}$ in a $5 \% \mathrm{CO}_{2}$ humidified atmosphere.

Cytotoxicity assay. Cytotoxicity was assessed by the standard MTT test (15) in conditions previously described (16). Briefly, cells were seeded at 10,000 cells/well in 96-well plates and allowed to growth for $24 \mathrm{~h}$. The medium was then changed and the cells were treated for 24,48 and $72 \mathrm{~h}$ with solutions containing the sulfur compounds.

Production and purification of the GST-Cdc25 fusion proteins in E. coli. Glutathione S-transferase (GST)-Cdc25 recombinant enzymes $\mathrm{Cdc} 25 \mathrm{~A}, \mathrm{Cdc} 25 \mathrm{~B}$ and $\mathrm{Cdc} 25 \mathrm{C}$ were obtained in our laboratory using transformed Escherichia coli BL21 (DE3) encoding the gene fusion constructs GSTCdc25s. Fusion proteins were expressed by induction with $0.5 \mathrm{mM}$ IPTG (isopropyl ß-D-thiogalactopyranoside, Eurobio, France) for $5 \mathrm{~h}$ at $30^{\circ} \mathrm{C}$. Then, cell pellets were thawed in $30 \mathrm{ml}$ of lysis buffer [50 mM Tris- $\mathrm{HCl} \mathrm{pH} 7.5,250 \mathrm{mM} \mathrm{NaCl}$, $1 \mathrm{mM}$ EDTA, $0.1 \%$ Triton X-100, 0.1 mM PMSF, 3\% (v/v) protease inhibitor cocktail (Sigma Chemical, USA)] and lysed by sonication $(5 \times 30 \mathrm{sec})$. After cell lysis, lysate was cleared by a $25,000 \times$ g centrifugation for $45 \mathrm{~min}$ and fusion proteins were purified by affinity chromatography using glutathione-agarose gel as described (17).

In vitro phosphatase assay. Prior to in vitro assays, enzymes were purified by a Microcon ${ }^{\circledR}$ centrifugal filter unit with cutoff of $30 \mathrm{kDa}$ (Millipore) in order to clear out of buffer containing reducing agents. Phosphatase activity was determined using 3-O-methyl fluorescein phosphate (OMFP) as substrate. The assay was performed in 96-well plates in a final volume of $100 \mu 1$. The final concentrations were $315 \mathrm{ng} /$ well for Cdc25 A, $500 \mathrm{ng} /$ well for Cdc25 B and $414 \mathrm{ng} /$ well for Cdc25 C. The concentrations of enzyme used in these assays allow to obtain comparable fluorescence values for each $\mathrm{Cdc} 25$ isoform. The enzymes were incubated with compounds for $1 \mathrm{~h}$ at $30^{\circ} \mathrm{C}$ in reaction buffer [50 mM Tris-HCl (pH 8.2), $50 \mathrm{mM} \mathrm{NaCl}, 1 \mathrm{mM}$ EDTA, 0.1\% SAB]. The reaction was initiated by adding $500 \mu \mathrm{M}$ of substrate. After $2 \mathrm{~h}$ at $30^{\circ} \mathrm{C}$, fluorescence emission from the dephosphorylated product, 3-O-methyl fluorescein (OMF), was measured with Cytofluor ${ }^{\circledR}$ (Biosystem; excitation filter: $485 \mathrm{~nm}$ and emission filter: $510 \mathrm{~nm}$ ). The efficiency of this method was controlled using a known Cdc25 inhibitor, BN82002 (Sigma-Aldrich) (18). Data represent means of at least three independent experiments. Determination of the median inhibitory concentration $\mathrm{IC}_{50}$ was performed using generalized linear models, as described (19).

Reversibility assays were performed by pre-incubating large amounts of Cdc $25 \mathrm{C}$ phosphatase $(10 \mu \mathrm{g})$ with inhibitory concentrations of $\mathrm{DAS}_{4}$ or $\mathrm{DPS}_{4}(10 \mu \mathrm{M})$ for various times (0-90 $\mathrm{min})$. Then, the enzyme-inhibitor mixture was 100 -fold diluted in reaction buffer [50 mM Tris- $\mathrm{HCl}(\mathrm{pH} 8.2), 50 \mathrm{mM}$ $\mathrm{NaCl}, 1 \mathrm{mM}$ EDTA, $0.1 \% \mathrm{SAB}$ ]. This dilution leads to a $0.1 \mu \mathrm{M}$ concentration of inhibitor, which is inactive towards Cdc25 C (not shown). Phosphatase activity was subsequently measured as described above in the presence of $414 \mathrm{ng} / \mathrm{well}$ of Cdc25 C and after adding $500 \mu \mathrm{M}$ of substrate (OMFP). Results are representative of four independent experiments.

Cellular growth assay. Cells were plated at a density of $2 \times 10^{5}$ per well in 6-well plates. After $24 \mathrm{~h}$, cells were treated with $\mathrm{DAS}_{4}$ or DPS 4 (25 and $\left.50 \mu \mathrm{M}\right)$ or solvent alone (DMSO, $0.5 \% \mathrm{v} / \mathrm{v})$. Treatment with DAS $(50 \mu \mathrm{M})$, a compound that does not inhibit the $\mathrm{Cdc} 25$ phosphatases, was used as negative control. At indicated time points, adherent cells were trypsinized and harvested together with the floating cells. Then, the total amount of cells was quantified by the trypan blue exclusion counting method over the following 4 days.

Cell cycle analysis. Cells $\left(1 \times 10^{6}\right)$ were seeded in $100-\mathrm{mm}$ dishes and allowed to attach overnight. Cells were exposed to $50 \mu \mathrm{M} \mathrm{DAS}{ }_{4}$ or $\mathrm{DPS}_{4}$. An experiment with solvent alone (DMSO, $0.5 \% \mathrm{v} / \mathrm{v})$ was performed as negative control. After incubation at $37^{\circ} \mathrm{C}$ for the desired time, floating and adherent cells were harvested, stained with propidium iodide solution $(50 \mu \mathrm{g} / \mathrm{ml})$ and analyzed for DNA content with FACSCalibur flow cytometer (Becton-Dickinson, USA). 
Table I. Structures of Allium compounds and screening for Cdc25 inhibition. ${ }^{\mathrm{a}}$

Residual activity of phosphatase

\begin{tabular}{|c|c|c|c|c|c|}
\hline & \multirow[t]{2}{*}{ Compound } & \multirow[t]{2}{*}{ Structure } & \multicolumn{3}{|c|}{ (\% of control) } \\
\hline & & & Cdc25 A & Cdc25 B & Cde25 C \\
\hline \multirow{6}{*}{ مِ } & Allicin & & $26 \pm 16$ & $67 \pm 8$ & $7 \pm 2$ \\
\hline & Diallyl sulfide (DAS) & & $116 \pm 4$ & $94 \pm 4$ & $88 \pm 8$ \\
\hline & Diallyl disulfide $\left(\mathrm{DAS}_{2}\right)$ & & $76 \pm 15$ & $97 \pm 6$ & $50 \pm 7$ \\
\hline & Diallyl trisulfide $\left(\mathrm{DAS}_{3}\right)$ & & $70 \pm 14$ & $87 \pm 6$ & $24 \pm 6$ \\
\hline & Diallyl tetrasulfide $\left(\mathrm{DAS}_{4}\right)$ & & $8 \pm 10$ & $48 \pm 6$ & $0 \pm 1$ \\
\hline & Allyl mercaptan & & $115 \pm 15$ & $94 \pm 4$ & $82 \pm 8$ \\
\hline \multirow{8}{*}{ 。气 } & Propyl allicin & & $48 \pm 11$ & $67 \pm 5$ & $16 \pm 4$ \\
\hline & Dipropyl sulfide (DPS) & & $119 \pm 17$ & $99 \pm 4$ & $96 \pm 4$ \\
\hline & Dipropyl disulfide $\left(\mathrm{DPS}_{2}\right)$ & & $99 \pm 4$ & $96 \pm 1$ & $68 \pm 3$ \\
\hline & Dipropyl trisulfide $\left(\mathrm{DPS}_{3}\right)$ & & $85 \pm 13$ & $84 \pm 2$ & $20 \pm 3$ \\
\hline & Dipropyl tetrasulfide $\left(\mathrm{DPS}_{4}\right)$ & & $12 \pm 8$ & $58 \pm 8$ & $2 \pm 2$ \\
\hline & Propyl mercaptan & & $100 \pm 22$ & $79 \pm 4$ & $50 \pm 3$ \\
\hline & 1,9-decadiene & & $129 \pm 18$ & $111 \pm 6$ & $99 \pm 14$ \\
\hline & 3-isothiocyanatopropene & & $116 \pm 12$ & $100 \pm 9$ & $72 \pm 8$ \\
\hline
\end{tabular}

aPhosphatase activity was evaluated using the OMFP dephosphorylation assay. The three isoforms of human Cdc25 phosphatases were incubated with $100 \mu \mathrm{M}$ of each compound for $1 \mathrm{~h}$ at $30^{\circ} \mathrm{C}$. Activity was expressed as $\%$ of residual activity of control in the absence of compound. Results are mean \pm SD of three independent experiments.

Cell lysate preparation and immunoblotting. MCF-7 cells were plated at a density of $1 \times 10^{6}$ in $100-\mathrm{mm}$ dishes. After $24 \mathrm{~h}$, the cells were treated with $\mathrm{DAS}_{4}$ and DPS 4 for 6 and $12 \mathrm{~h}$. Cells were then harvested and lysed in lysis buffer $[10 \mathrm{mM}$ Tris- $\mathrm{HCl}$ (pH 7.5), $100 \mathrm{mM} \mathrm{NaCl}, 1 \%$ Triton X-100, $1 \mathrm{mM}$ EDTA, 1 mM EGTA, 1 mM NaF, 0.1\% SDS, 10\% glycerol, $0.5 \%$ deoxycholate supplemented with protease inhibitors cocktail (Sigma Chemical), $1 \mathrm{mM}$ PMSF and $\left.2 \mathrm{mM} \mathrm{Na}_{3} \mathrm{VO}_{4}\right]$ for $30 \mathrm{~min}$ on ice. Then, the cells were sonicated (3 times for $10 \mathrm{sec}$, VibraCell, Fisher Bioblock Scientific, Illkirch, France) and centrifuged $\left(12,000 \mathrm{x} \mathrm{g}, 15 \mathrm{~min}, 4^{\circ} \mathrm{C}\right)$. Lysate proteins $(50 \mu \mathrm{g})$ were separated on a $14 \%$ gel by SDS-PAGE and transferred on a nitrocellulose membrane. Immunoblotting was performed using anti-phospho-Cdk2 (1:1000) (Santa Cruz Biotechnology), anti-phospho-Cdk1 (1:1000) (Cell Signaling Technology). Primary antibodies were detected with horseradish peroxidase-goat anti-rabbit antibody (KPL). Densitometry analysis was performed using ChemiDoc ${ }^{\mathrm{TM}}$ (Bio-Rad) and relative quantifications of phospho-Cdk1 and
phospho-Cdk2 were performed in comparison with loading control ( $\alpha$-tubulin).

Statistical analysis. Data represent the mean of at least three independent experiments. Statistical analysis was performed using a Student's t-test.

\section{Results}

In vitro inhibition of phosphatase activity. Sulfur compounds naturally present in garlic and onion have been evaluated for their ability to inhibit the activities of human $\mathrm{Cdc} 25 \mathrm{~A}$, $\mathrm{Cdc} 25 \mathrm{~B}$ and Cdc25 C. These enzymes are routinely expressed and purified in our laboratory, and serve as useful tools for the study of Cdc25 inhibition (20). A preliminary screening, performed with a single dose of each compound $(100 \mu \mathrm{M})$, indicates that the highest inhibitory activities were found for the polysulfides $\mathrm{DAS}_{4}$ and $\mathrm{DPS}_{4}$ (Table I). The most potent inhibitory effects were observed against the purified 
Table II. Inhibition of purified recombinant members of Cdc25 family with $\mathrm{DAS}_{4}$ and $\mathrm{DPS}_{4} \cdot{ }^{\mathrm{a}}$

\begin{tabular}{lccccc}
\hline & \multicolumn{2}{c}{$\mathrm{DAS}_{4}$} & & \multicolumn{2}{c}{$\mathrm{DPS}_{4}$} \\
\cline { 2 - 3 } \cline { 5 - 6 } & $\mathrm{IC}_{50}(\mu \mathrm{M})$ & $\mathrm{SD}$ & $\mathrm{IC}_{50}(\mu \mathrm{M})$ & $\mathrm{SD}$ \\
\hline $\mathrm{Cdc} 25 \mathrm{~A}$ & 16.4 & 5.5 & & 16.6 & 5.5 \\
$\mathrm{Cdc} 25 \mathrm{~B}$ & $>100$ & - & $>100$ & - \\
$\mathrm{Cdc} 25 \mathrm{C}$ & 1.1 & 0.1 & & 1.4 & 0.2 \\
\hline
\end{tabular}

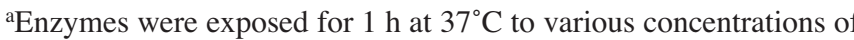
DAS $_{4}$ or DPS $4(0-200 \mu \mathrm{M})$. Phosphatase activity was determined using the OMFP dephosphorylation assay. $\mathrm{The} \mathrm{IC}_{50}$ values were determined using GLMTox from at least three independent experiments (19)

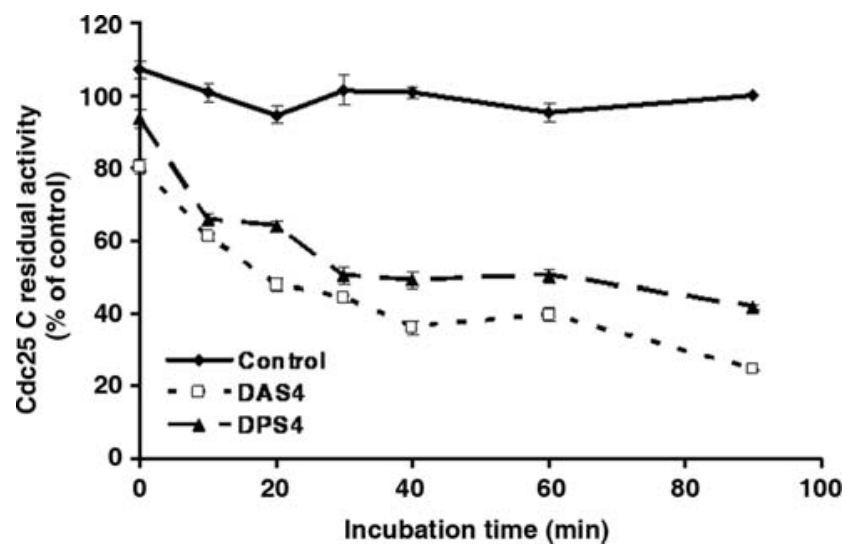

Figure 1. Reversibility assay of Cdc25 C inhibition by $\mathrm{DAS}_{4}$ and $\mathrm{DPS}_{4}$ $\mathrm{Cdc} 25 \mathrm{C}$ phosphatase was preincubated with solvent alone (control) or inhibitory concentrations of $\mathrm{DAS}_{4}$ or $\mathrm{DPS}_{4}(10 \mu \mathrm{M})$ for various time intervals (0-90 $\mathrm{min})$. After incubation, the reaction mixture was diluted 100-fold to reach inactive concentrations of $\mathrm{DAS}_{4}$ or $\mathrm{DPS}_{4}(0.1 \mu \mathrm{M})$. The phosphatase activity was determined by adding the substrate OMFP in each well containing $414 \mathrm{ng}$ of $\mathrm{Cdc} 25 \mathrm{C}$ after dilution. Data are representative of four independent experiments.

recombinant fusion proteins $\mathrm{Cdc} 25 \mathrm{C}$ and $\mathrm{Cdc} 25 \mathrm{~A}$, whereas Cdc25 B was less sensitive.

The most active compounds of this study, $\mathrm{DAS}_{4}$ and $\mathrm{DPS}_{4}$, were therefore chosen for a more complete evaluation of their potential. As indicated in Table II, the highest inhibitory activity was found toward $\mathrm{Cdc} 25 \mathrm{C}$ with $\mathrm{IC}_{50}$ values of $1.1 \pm 0.1$ and $1.4 \pm 0.2 \mu \mathrm{M}$ for $\mathrm{DAS}_{4}$ and $\mathrm{DPS}_{4}$, respectively. Concentrations required to inhibit $\mathrm{Cdc} 25 \mathrm{~A}$ activity $\left(\mathrm{IC}_{50}\right.$ values of $16.4 \pm 5.5$ and $16.6 \pm 5.5 \mu \mathrm{M}$, respectively) were 10 -fold higher than those used for Cdc25 C. However, the inhibitory effects were very weak toward $\mathrm{Cdc} 25 \mathrm{~B}\left(\mathrm{IC}_{50}>100 \mu \mathrm{M}\right.$ for both compounds), according to results obtained in Table I. We noted that both, allyl- and propyl-derivatives inhibited Cdc 25 activity in a similar range of concentrations.

We further examined whether the inhibition achieved by these two compounds is reversible or not. Cdc $25 \mathrm{C}$ phosphatase was preincubated for various times (0-90 $\mathrm{min})$ with solvent alone (control) or active concentrations of $\mathrm{DAS}_{4}$ and
Table III. Cytotoxic effects of $\mathrm{DAS}_{4}$ and $\mathrm{DPS}_{4}$ on MCF-7 human mammary cell line. ${ }^{\mathrm{a}}$

\begin{tabular}{ccccccc}
\hline & \multicolumn{2}{c}{$\mathrm{DAS}_{4}$} & & \multicolumn{2}{c}{$\mathrm{DPS}_{4}$} \\
\cline { 3 - 4 } \cline { 6 - 7 } & & $\mathrm{IC}_{50}(\mu \mathrm{M})$ & $\mathrm{SD}$ & & $\mathrm{IC}_{50}(\mu \mathrm{M})$ & $\mathrm{SD}$ \\
\hline \multirow{2}{*}{$\mathrm{MCF}-7$} & $24 \mathrm{~h}$ & 92 & 14 & & $>100$ & \\
& $48 \mathrm{~h}$ & 43 & 12 & 25 & 4 \\
& $72 \mathrm{~h}$ & 25 & 7 & & 23 & 3 \\
\hline
\end{tabular}

${ }^{\text {a MCF-7 }}$ cells were exposed for 24,48 and $72 \mathrm{~h}$ to various concentrations of $\mathrm{DAS}_{4}$ or $\mathrm{DPS}_{4}$ and cytotoxicity was evaluated performing MTT test. The $\mathrm{IC}_{50}$ values were calculated using GLMTox $(\mathrm{n}=3)$.

DPS $_{4}(10 \mu \mathrm{M})$. Then, the reaction mixture was diluted to a final concentration of $0.1 \mu \mathrm{M}$ at which the inhibitors are inactive (data not shown). If the inhibitory effects persist after dilution, the mechanism of action should be considered as irreversible (21). As indicated in Fig. 1, for $\mathrm{DAS}_{4}$ and $\mathrm{DPS}_{4}$, the inhibitory activity persisted after the dilution procedure in absence of reducing agent. Moreover, both compounds inhibited $\mathrm{Cdc} 25 \mathrm{C}$ in a time-dependent manner with a maximal inhibitory activity observed after $90 \mathrm{~min}$ of preincubation (25 and $42 \%$ of residual activity, respectively). These results suggest that $\mathrm{DAS}_{4}$ and $\mathrm{DPS}_{4}$ act as irreversible inhibitors of the $\mathrm{Cdc} 25$ phosphatases in vitro. However, polysulfides are able to react with thiols to form $\mathrm{S}$-thiolated proteins, a reaction known as reversible (4). Thus, we may envisage that the inhibitory activities of $\mathrm{DAS}_{4}$ and $\mathrm{DPS}_{4}$ are chemically reversible in presence of reducing agents such as dithiothreitol (DTT) and glutathione (GSH). This was confirmed by additional experiments performed on purified $\mathrm{Cdc} 25 \mathrm{~A}$ in vitro in presence of reducing agents (DTT and GSH). Our results indicated that the ability of the tetrasulfides to inhibit Cdc25 A was reduced in presence of DTT and GSH (data not shown).

Effect on breast cancer cell viability. The cytotoxic effects of $\mathrm{DAS}_{4}$ and $\mathrm{DPS}_{4}$ were first evaluated on the human mammary adenocarcinoma cell line MCF-7. As shown in Table III, DPS $_{4}$ displayed cytotoxic effects with $\mathrm{IC}_{50}$ of $25 \pm 4$ and $23 \pm 3 \mu \mathrm{M}$ after 48 and $72 \mathrm{~h}$ treatment, respectively. $\mathrm{DAS}_{4}$ showed a concentration- and time-dependent cytotoxic activity with $\mathrm{IC}_{50}$ of $92 \pm 14,43 \pm 12$ and $25 \pm 7 \mu \mathrm{M}$ after 24,48 and $72 \mathrm{~h}$ treatment, respectively.

To determine the antiproliferative effects of both tetrasulfur compounds, MCF-7 cells were treated with $\mathrm{DAS}_{4}$ and $\mathrm{DPS}_{4}$ (25 and $50 \mu \mathrm{M})$ and cell growth curves $(0-96 \mathrm{~h})$ were plotted (Fig. 2A and B). DAS $(50 \mu \mathrm{M})$, a non-inhibitory compound, was used as negative control, and DMSO $(0.5 \% \mathrm{v} / \mathrm{v})$ as a solvent control. $\mathrm{DAS}_{4}$ and $\mathrm{DPS}_{4}$ appeared to significantly reduce the cell growth whereas neither DAS $(50 \mu \mathrm{M})$ nor DMSO alone showed any effect. These data suggest a cytostatic effect of both tested compounds against MCF-7 cells.

We then explored the effect of $\mathrm{DAS}_{4}$ and $\mathrm{DPS}_{4}$ on a second breast cancer derived cell line, Vcr-R, which presents 
A

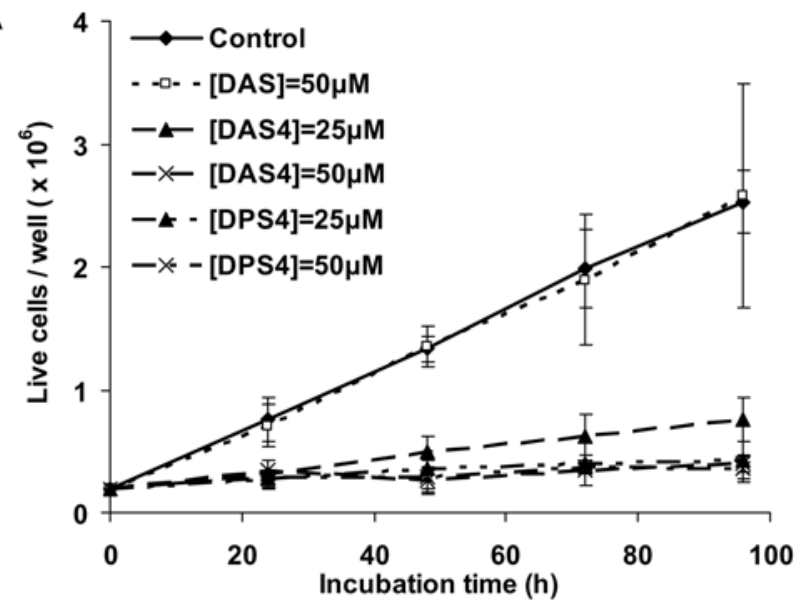

C

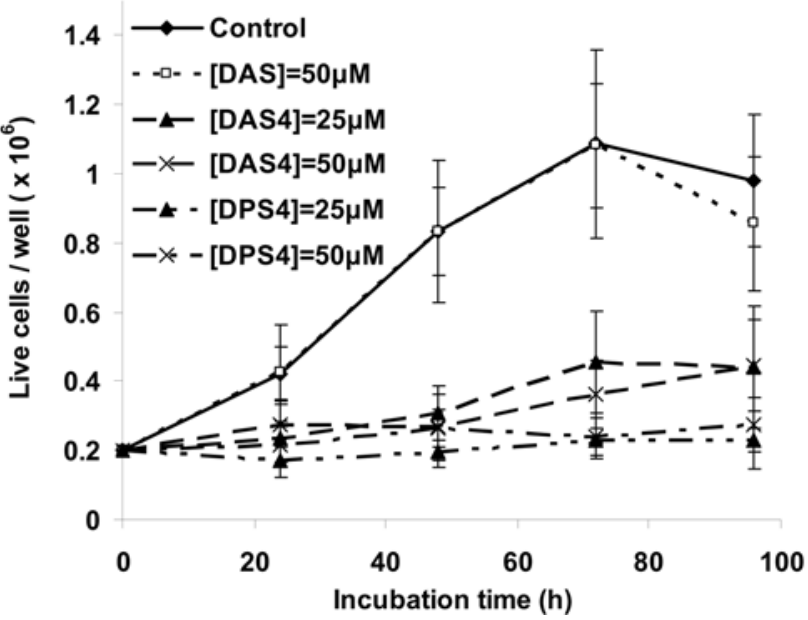

B

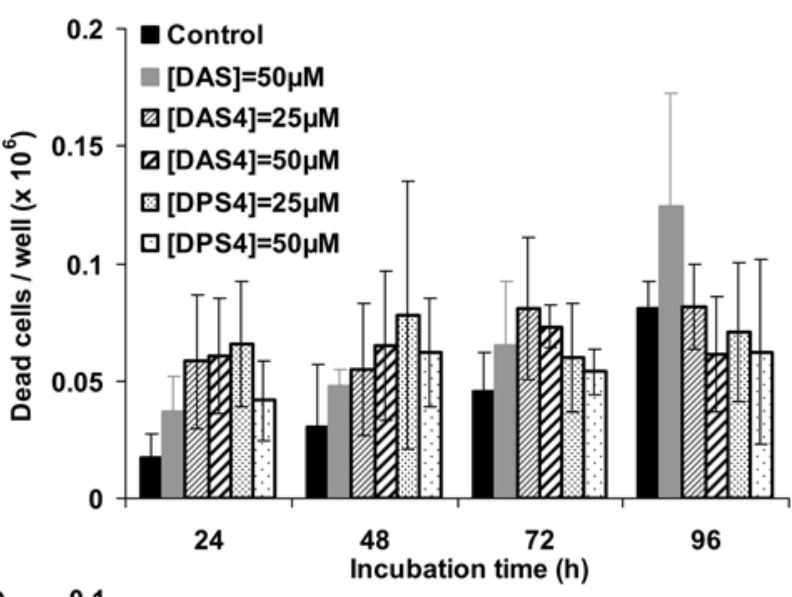

D

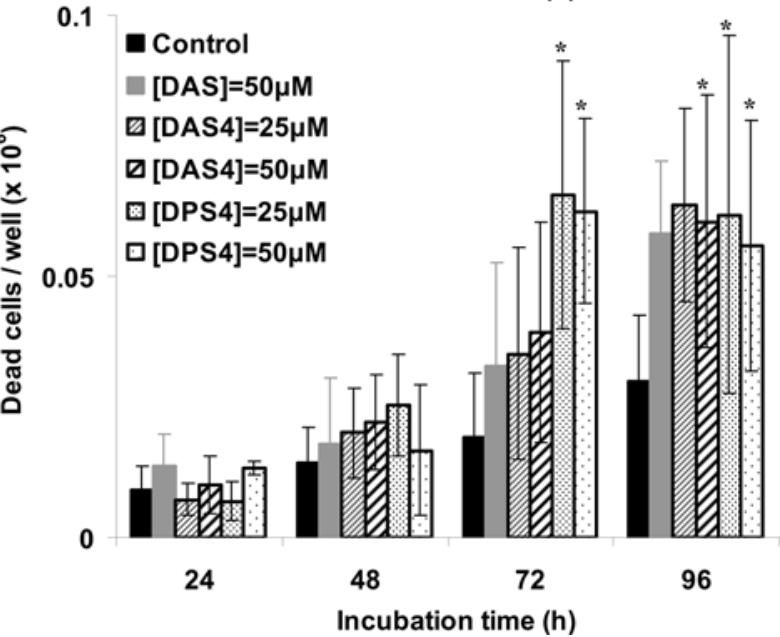

Figure 2. Effect of DAS 4 and DPS 4 on breast cancer cell growth. Cells were exposed to DAS, DAS 4 or DPS 4 and quantified by the trypan blue exclusion counting method. (A) Quantification of living MCF-7 cells. (B) Quantification of dead MCF-7 cells. (C) Quantification of living Vcr-R cells. (D) Quantification of dead Vcr-R cells. Values reported were calculated from three independent experiments.

multi-drug resistance towards vincristine, adriamycin and etoposide associated to over-expression of P-glycoprotein and glutathione S-transferase (GST) pi (14). As for MCF-7, MTT tests pointed towards a cytotoxic activity of $\mathrm{DAS}_{4}$ and $\mathrm{DPS}_{4}$ after 48 and $72 \mathrm{~h}$ treatment (data not shown). However, these effects appeared to be less dramatic when compared to $\mathrm{MCF}-7$ cells $\left(\mathrm{IC}_{50}\right.$ up to $\left.100 \mu \mathrm{M}\right)$. Vcr-R cell growth was markedly reduced in the presence of $\mathrm{DAS}_{4}$ and $\mathrm{DPS}_{4}$ (Fig. 2C and D).

Effect on cell cycle progression. The Cdc25 phosphatases are known to play an essential role in cell proliferation. The enzymatic in vitro experiments demonstrate the inhibitory potential of $\mathrm{DAS}_{4}$ and $\mathrm{DPS}_{4}$ towards the $\mathrm{Cdc} 25$ phosphatase activities (Table II) and these results suggest that these compounds could lead to a cell cycle arrest in cultured cells. The effects of $\mathrm{DAS}_{4}$ and $\mathrm{DPS}_{4}$ on cell cycle progression have then been determined by flow cytometry after propidium iodide staining. Compared with the control (DMSO, 0.5\% v/v), MCF-7 cells displayed a $\mathrm{G}_{2}-\mathrm{M}$ phase arrest after incubation with $50 \mu \mathrm{M} \mathrm{DAS}_{4}$ and $\mathrm{DPS}_{4}$ (Fig. 3A). This cell cycle blockage was observed as soon as $3 \mathrm{~h}$ after treatment commenced and remained up to $48 \mathrm{~h}$. For example, as shown in Table IV, the cellular population at $\mathrm{G}_{2}-\mathrm{M}$ phase was markedly increased (56 and $80 \%$, respectively, compared to $18 \%$ for control) when $\mathrm{DAS}_{4}$ or $\mathrm{DPS}_{4}$ were added to the cultures for $24 \mathrm{~h}$.

Flow cytometry analysis confirmed that the antiproliferative effect could also be observed on Vcr-R and was associated with a $\mathrm{G}_{2}-\mathrm{M}$ cell cycle arrest. As shown in Fig. 3B, this inhibition appeared as soon as $3 \mathrm{~h}$ after treatment commenced and was most significant after $24 \mathrm{~h}$ of treatment with $\mathrm{DAS}_{4}$ and $\mathrm{DPS}_{4}$ (63 and 61\%, respectively, compared to $8 \%$ for control, as described in Table IV). In contrast to MCF-7 cells, the cell cycle resumed after 48 h treatment: increases in the proportion of Vcr-R cells in the S phase (33 and $48 \%$ for treatment with $50 \mu \mathrm{M}$ of $\mathrm{DAS}_{4}$ and $\mathrm{DPS}_{4}$, compared to $15 \%$ for control) were observed (data not shown).

Effect of $\mathrm{DAS}_{4}$ or $\mathrm{DPS}_{4}$ on tyrosine phosphorylation of Cdk1 and Cdk2 in MCF-7 cells. We finally assessed whether the $\mathrm{G}_{2}-\mathrm{M}$ blockage, observed in MCF-7 cells treated with $\mathrm{DAS}_{4}$ and $\mathrm{DPS}_{4}(50 \mu \mathrm{M})$, was effectively related to the ability of both compounds to inhibit $\mathrm{Cdc} 25$ phosphatases in cells. The inhibition of the cellular Cdc25 phosphatases led to an accumulation of the inactive phosphorylated forms of Cdk 
Table IV. Effects of $\mathrm{DAS}_{4}$ and $\mathrm{DPS}_{4}$ on the cell cycle. ${ }^{\mathrm{a}}$

\begin{tabular}{|c|c|c|c|c|c|c|}
\hline \multirow[b]{3}{*}{ Treatment } & \multicolumn{6}{|c|}{ Percent cells in } \\
\hline & \multicolumn{3}{|c|}{ MCF-7 } & \multicolumn{3}{|c|}{ Vcr-R } \\
\hline & $\mathrm{G}_{0}-\mathrm{G}_{1}$ & $\mathrm{~S}$ & $\mathrm{G}_{2}-\mathrm{M}$ & $\mathrm{G}_{0}-\mathrm{G}_{1}$ & $\mathrm{~S}$ & $\mathrm{G}_{2}-\mathrm{M}$ \\
\hline Control (DMSO) & 61 & 21 & 18 & 76 & 16 & 8 \\
\hline $\mathrm{DAS}_{4}(50 \mu \mathrm{M})$ & 38 & 6 & 56 & 8 & 29 & 63 \\
\hline $\mathrm{DPS}_{4}(50 \mu \mathrm{M})$ & 18 & 2 & 80 & 6 & 33 & 61 \\
\hline
\end{tabular}

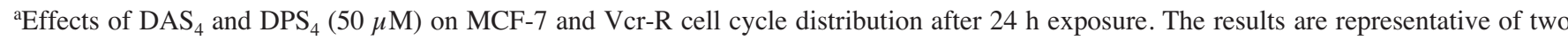
independent experiments.

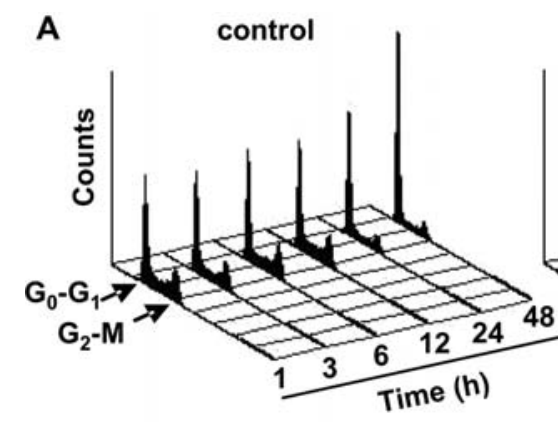

$\mathrm{DAS}_{4}(50 \mu \mathrm{M})$

$\mathrm{DPS}_{4}(50 \mu \mathrm{M})$
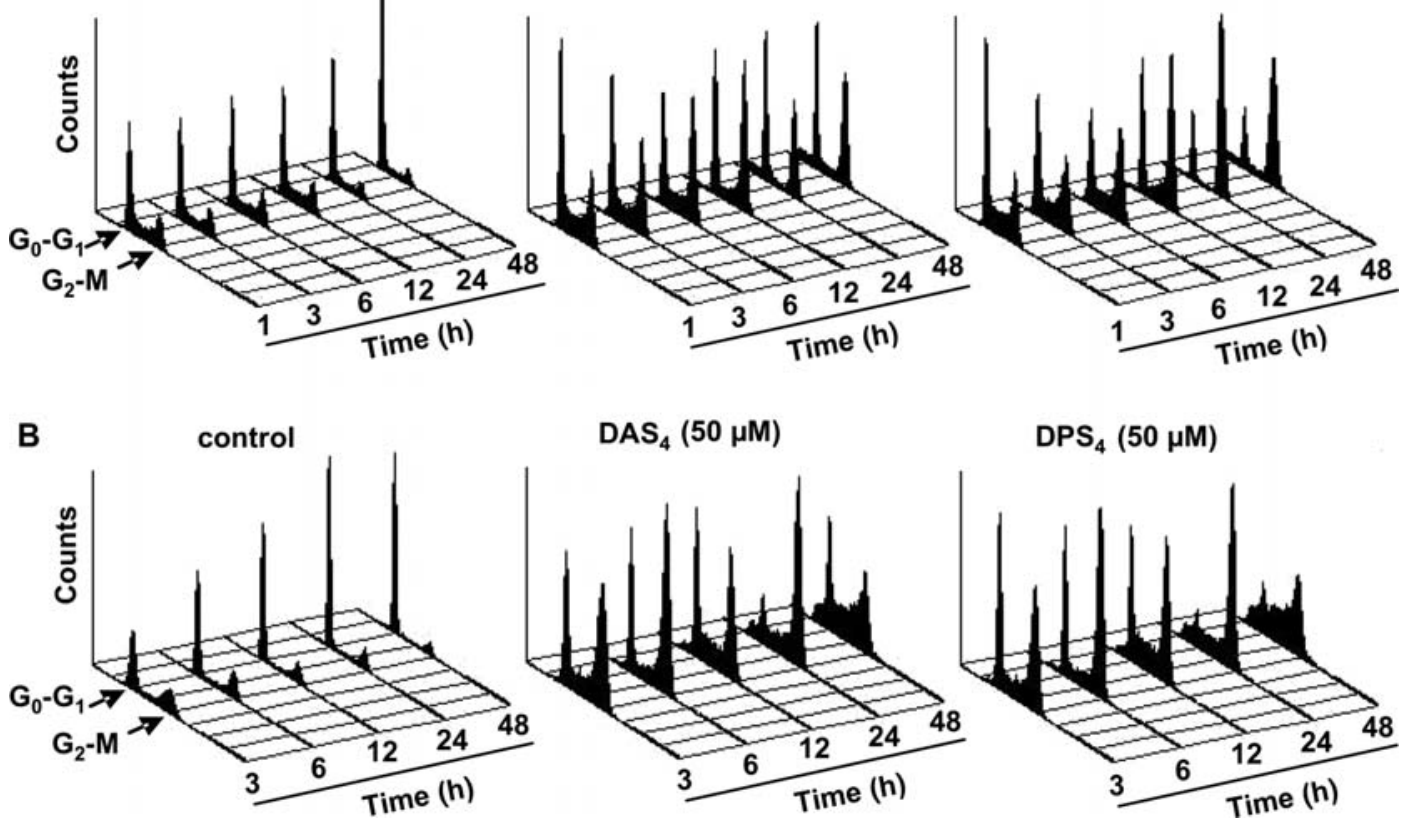

$\mathrm{DAS}_{4}(50 \mu \mathrm{M})$

$\mathrm{DPS}_{4}(50 \mu \mathrm{M})$
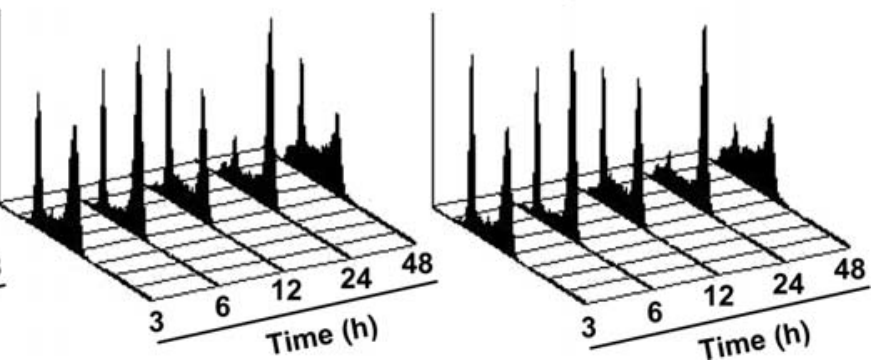

Figure 3. Effect of DAS 4 and DPS 4 on breast cancer cell cycle. (A) Representative histograms of MCF-7 cell cycle phase distribution in cultures treated with solvent alone (control), $\mathrm{DAS}_{4}$ or $\mathrm{DPS}_{4}(50 \mu \mathrm{M})$ for the indicated time periods. (B) Representative histograms of Vcr-R cell cycle phase distribution in cultures treated with solvent alone (control), $\mathrm{DAS}_{4}$ or $\mathrm{DPS}_{4}(50 \mu \mathrm{M})$ for the indicated time periods.

(cyclin-dependent kinases). Fig. 4A clearly shows that $\mathrm{DAS}_{4}$ and $\mathrm{DPS}_{4}(50 \mu \mathrm{M})$ led to an accumulation of the phosphorylated forms of $\mathrm{Cdk} 1$ and 2. After quantitative analysis, these compounds appeared to induce accumulation of $\mathrm{p}-\mathrm{Cdk} 1$ (1.6- and 1.7-fold increase compared to control, respectively) and p-Cdk2 (2.1- and 2.5-fold increase, respectively) after short-time treatment of $6 \mathrm{~h}$ (Fig. 4B), in agreement with an inhibition of Cdc25 C and A. As shown in Fig. 4, accumulations of $\mathrm{p}-\mathrm{Cdk} 1$ and $\mathrm{p}-\mathrm{Cdk} 2$ did not persist for a longer incubation time (12 h) with $\mathrm{DAS}_{4}$ and $\mathrm{DPS}_{4}$ (Fig. 4A and C).

\section{Discussion}

Recent studies have confirmed that various organic sulfur compounds exhibit anticancer properties (22) and their efficiency was demonstrated in vitro and in vivo on various cancer types $(5-8,23)$. These compounds appear to target different signaling pathways to inhibit cancer cell proliferation. Chemistry of the naturally occurring sulfides is very complex and mechanisms involved are not yet fully elucidated. For instance, reactive oxygen species (ROS) generation seems to be one of the antiproliferative mechanisms of such compounds in cancer cells, but ROS levels seem to be closely dependent of the cell lines tested. For example, Cerella et al have reported that polysulfides induced a caspase-dependent apoptosis in U937 leukemia cells by activation of pro-apoptotic Bcl-2 family members and the release of the cytochrome $\mathrm{c}$ into the cytoplasm without ROS production (24). In contrast, Hosono et al showed that $\mathrm{DAS}_{3}$ led to the formation of ROS in colon cancer cells, causing B-tubulin oxidation and the disruption of the microtubule network, thus affecting the formation of 
A
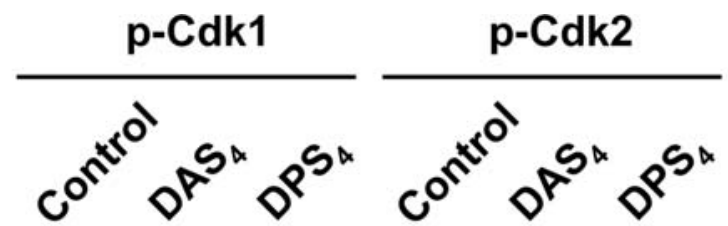

$\alpha-T u b u l i n$
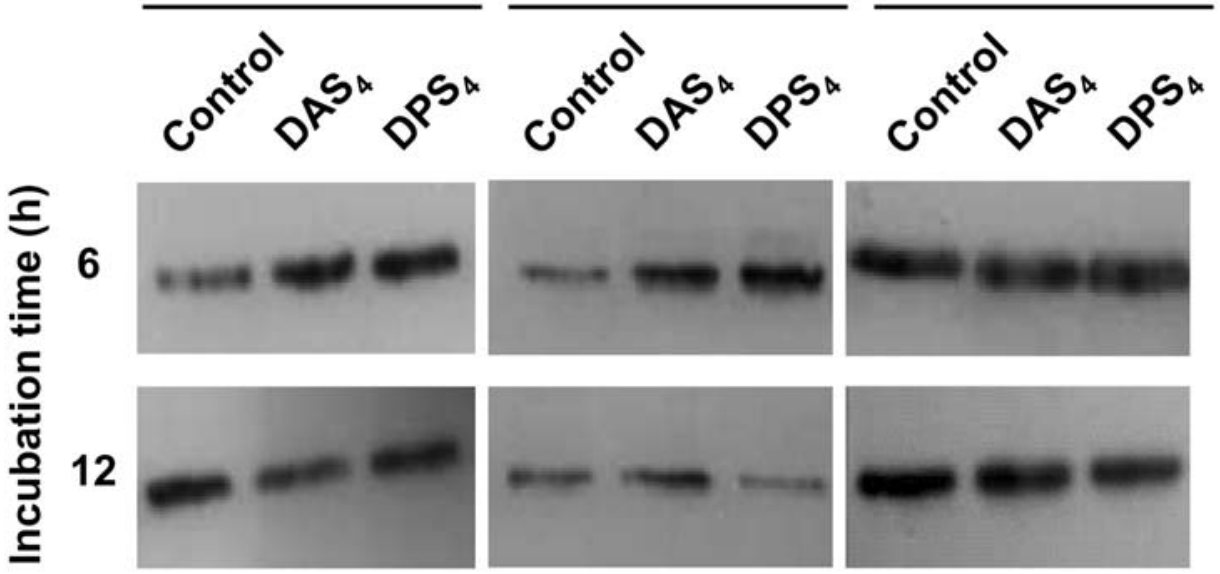

B
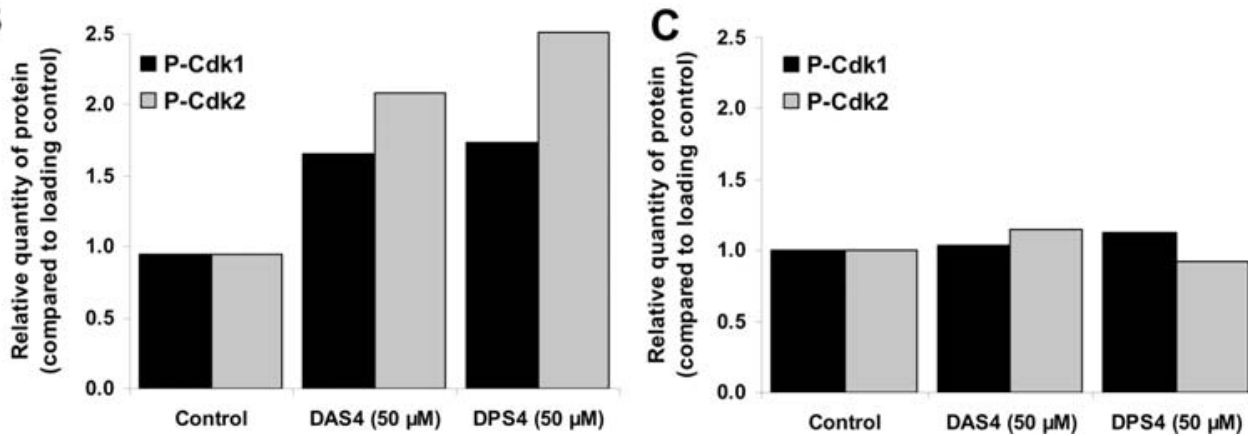

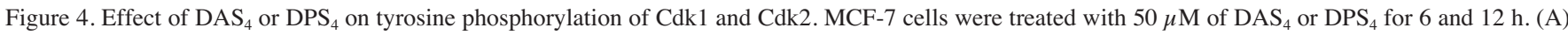
After indicated time treatment cells were harvested and analyzed by immunoblotting. $\alpha$-tubulin level was used as loading control. (B and C) Relative quantifications of phospho-Cdk1 and phospho-Cdk2 were performed in comparison with loading control ( $\alpha$-tubulin) after $6 \mathrm{~h}(\mathrm{~B})$ and $12 \mathrm{~h}(\mathrm{C})$ treatment.

mitotic spindles, and ultimately leading to apoptosis after a $\mathrm{G}_{2}-\mathrm{M}$ phase arrest (25). Other studies have associated Cdc 25 $\mathrm{C}$ with the cell cycle arrest. Indeed, results obtained by Xiao et al indicated that $\mathrm{DAS}_{3}$-treated prostate cancer cells exhibited a decrease in Cdc $25 \mathrm{C}$ protein level and an increase in its Ser216 phosphorylation, creating a binding site for 143-3 cytoplasmic protein (7). More recently, they have reported that the $\mathrm{DAS}_{3}$-mediated $\mathrm{G}_{2}-\mathrm{M}$ cell cycle arrest was associated with a down-regulation of $\mathrm{Cdc} 25 \mathrm{C}$ expression (26). The latter study also shows that the induction of proapoptotic proteins and the decrease of anti-apoptotic proteins seem to be crucial in apoptosis induction.

Other mechanisms displayed by sulfides have been reported and include the phenomenon of histone hyperacetylation in human colon tumor cell lines (27).

In the study reported here, we investigated the effects of $\mathrm{DAS}_{4}$ and $\mathrm{DPS}_{4}$ in MCF-7-cultured cells, used as model of breast cancer. The analysis of MCF-7 cell growth, in the presence of both $\mathrm{DAS}_{4}$ and $\mathrm{DPS}_{4}$, suggests a cytostatic effect. Indeed, both compounds reduce the cell growth inducing a $\mathrm{G}_{2}-\mathrm{M}$ phase arrest. Interestingly, in this study, we have also observed very similar effects of $\mathrm{DAS}_{4}$ and $\mathrm{DPS}_{4}$ in the vincristine-resistant Vcr-R cell line derived from its sensitive counterpart MCF-7. In these cells, the polysulfides exhibited cytostatic properties, with a significant cell accumulation in $\mathrm{G}_{2}-\mathrm{M}$ phase, persisting up to $24 \mathrm{~h}$. In contrast to the cytotoxic effects of polysulfides reported in the literature, we observed that few or no cell death was induced in MCF-7 and Vcr-R after treatment with $\mathrm{DAS}_{4}$ and $\mathrm{DPS}_{4}$ (Fig. 2B and D). One explanation could be that the doses used in our experiments were too low to induce apoptosis in these cell lines. Moreover, caspase 3, a key player of the programmed cell death mechanism appears to have a critical role in OSC-induced apoptosis (25), and its deficiency observed in MCF-7 and Vcr-R could suggest that these cells are more resistant to apoptosis compared to caspase 3 positive ones.

Our study demonstrates for the first time the in vitro irreversible inhibitory activity of $\mathrm{DAS}_{4}$ and $\mathrm{DPS}_{4}$ towards Cdc25 $\mathrm{C}$ and $\mathrm{A}$. Interestingly, $\mathrm{DAS}_{4}$ and $\mathrm{DPS}_{4}$, the most potent compounds, preferentially inhibit $\mathrm{Cdc} 25 \mathrm{C}$ and $\mathrm{A}$ rather than Cdc25 B. These three isoenzymes show a highly conserved catalytic site in the $\mathrm{C}$-terminal domain of the proteins where the motif $\left(\mathrm{HCX}_{5} \mathrm{R}\right)$ is found, containing the catalytic cysteine. Our results suggest that the inhibitory potential of the organosulfur compounds studied is dependent upon the sulfur chain length (Cdc25 inhibitory activity decreases from tetra- to monosulfide). Our observations are in agreement with those reported by $\mathrm{Wu}$ and colleagues who found that the number of sulfur atoms in allylsulfides was correlated with the ability to inhibit the growth of the human liver tumor cells (J5) (28). One explanation for this observation is the complicated reactivity of polysulfides against proteins. Indeed, polysulfides are able to react with proteins to produce various types of modifications including oxidation, hydrophobic 
interactions, or to induce radical generation, events which are able to lead to modifications of protein reactivity (4). Moreover, we found that the inhibitory activities of allyl- and propylsulfides are comparable, indicating that the presence of double bonds found in the allyl compounds seems to be not essential. Contrarily, it has been reported that the mono- and disulfides, as well as the carbon analogue of the tetrasulfide display no activity (29).

The effects observed in vitro with purified enzymes were confirmed in MCF-7 cells. The inhibition of the cell cycle appears rapidly ( $3 \mathrm{~h}$ ) and is maintained up to $48 \mathrm{~h}$. The cause leading to this early and persisting blockage of the cell progression could be due to the fact that $\mathrm{DAS}_{4}$ and $\mathrm{DPS}_{4}$ act as irreversible inhibitors of $\mathrm{Cdc} 25 \mathrm{C}$. Although, $\mathrm{Cdc} 25 \mathrm{C}$ is required for entry into mitosis and to promote $\mathrm{S}$ phase entry in addition to the isoform $\mathrm{A}$, it seems to play a significant role in the control of the $\mathrm{G}_{2}-\mathrm{M}$ transition (10). Thus, the targeting of several Cdc25 isoforms by $\mathrm{DAS}_{4}$ and $\mathrm{DPS}_{4}$ probably enhances their ability to efficiently block the cell cycle.

Moreover, the rapid accumulation of $\mathrm{p}-\mathrm{Cdk} 1$ and $\mathrm{p}-\mathrm{Cdk} 2$ (up to $6 \mathrm{~h}$ ) confirms the inhibitory activity of $\mathrm{DAS}_{4}$ and $\mathrm{DPS}_{4}$ in cells. These results are in agreement with those of Herman-Antosiewicz et al who observed an accumulation of $\mathrm{p}-\mathrm{Cdk} 1$ in human prostate cancer cells (PC-3) after shorttime treatment by $\mathrm{DAS}_{3}(40 \mu \mathrm{M}$ for $8 \mathrm{~h})$. This accumulation of p-Cdk1 also appears to be related to Checkpoint Kinase 1 activation and $\mathrm{G}_{2}-\mathrm{M}$ cell cycle arrest (30). However, these effects seem to weaken with time. An explanation for this observation could be a possible chemical reduction of organic sulfur compounds by intracellular thiols, such as reduced glutathione (GSH) as already suggested $(4,31)$. Available data on GSH reactivity towards polysulfides and their products do not allow predicting how fast intracellular effects of such sulfides may be overcome in cells.

Finally, the biological activity of polysulfides can be explained by their ability to react with thiols, including cysteine residues in proteins, via thiol-disulfide and -polysulfide exchange. This leads to the formation of mixed disulfides, for instance in form of S-thiolated proteins and enzymes (4). Cdc25 phosphatases are potential targets of sulfur-containing compounds because of the presence of an active cysteine residue in the catalytic domain (32). Rudolph has shown that the $\mathrm{Cdc} 25$ phosphatases are sensitive towards redox modifications in vitro. Indeed, the active-site cysteine is susceptible to oxidation, which leads to protein inactivation (33). While, in our experiments, no change in ROS levels was observed after short and long time treatments with $\mathrm{DAS}_{4}$ and $\mathrm{DPS}_{4}$ (data not shown), we cannot exclude a direct interaction of polysulfides-enzyme in another site than the active site.

Taken together, our results, obtained in vitro on purified enzymes and in cell cultures, demonstrate that $\mathrm{Cdc} 25$ phosphatase inhibition is a mechanism by which the tetrasulfide derivatives $\left(\mathrm{DAS}_{4}\right.$ and $\left.\mathrm{DPS}_{4}\right)$ may cause cell arrest in breast cancer cells. Moreover, the anticancer effects reported on both the sensitive MCF-7 cells and their resistant Vcr-R counterparts point towards promising avenues of the tetrasulfide compounds (and derivatives) as part of a wider anticancer strategy.

\section{Acknowledgements}

The authors thank L. Meijer and I. Hoffmann for providing the expression plasmids for Cdc25s. E.V. is recipient of a fellowship from the Ministère de l'Enseignement Supérieur et de la Recherche. The research leading to these results has received funding from the (European Community's) Seventh Framework Programme ([FP7/2007-2013] under grant agreement no. 215009, and from The Ligue Contre le Cancer (Commitees 54, 55, 57). Research in LBMCC is supported by the Fondation de Recherche Cancer et Sang, Recherches Scientifiques Luxembourg asbl, Télévie, Een Häerz fir Kriibskrank Kanner asbl and the Action Lions Vaincre le Cancer. M.D. thanks the Foundation for Scientific Cooperation between Germany and Luxemburg for their support.

\section{References}

1. Hsing AW, Chokkalingam AP, Gao YT, Madigan MP, Deng J, Gridley G and Fraumeni JF: Allium vegetables and risk of prostate cancer: a population-based study. J Natl Cancer Inst 94: 1648-1651, 2002

2. Jacob C and Anwar A: Sulfides in Allium vegetables. In: Chemoprevention of Cancer and DNA Damage by Dietary Factors. Knasmüller S, DeMarini D, Johnson IT and Gerhäuser C (eds). Wiley-VCH, Weinheim, pp663-684, 2009.

3. You WC, Blot WJ, Chang YS, Ershow A, Yang ZT, An Q, Henderson BR, Fraumeni JF and Wang TG: Allium vegetables and reduced risk of stomach cancer. J Natl Cancer Inst 81: $162-164,1989$.

4. Münchberg U, Anwar A, Mecklenburg S and Jacob C: Polysulfides as biologically active ingredients of garlic. Org Biomol Chem 5: 1505-1518, 2007.

5. Shukla Y and Kalra N: Cancer chemoprevention with garlic and its constituents. Cancer Lett 247: 167-181, 2007.

6. Jo HJ, Song JD, Kim KM, Cho YH, Kim KH and Park YC: Diallyl disulfide induces reversible G2/M phase arrest on a p53independent mechanism in human colon cancer HCT-116 cells. Oncol Rep 19: 275-280, 2008

7. Xiao D, Herman-Antosiewicz A, Antosiewicz J, Xiao H, Brisson M, Lazo JS and Singh SV: Diallyl trisulfide-induced $\mathrm{G}(2)-\mathrm{M}$ phase cell cycle arrest in human prostate cancer cells is caused by reactive oxygen species-dependent destruction and hyperphosphorylation of Cdc 25 C. Oncogene 24: 6256-6268, 2005.

8. Xiao D, Lew KL, Kim YA, Zeng Y, Hahm ER, Dhir R and Singh SV: Diallyl trisulfide suppresses growth of PC-3 human prostate cancer xenograft in vivo in association with Bax and Bak induction. Clin Cancer Res 12: 6836-6843, 2006.

9. Boutros R, Lobjois V and Ducommun B: CDC25 phosphatases in cancer cells: key players? Good targets? Nat Rev Cancer 7: 495-507, 2007.

10. Boutros R, Dozier C and Ducommun B: The when and wheres of CDC25 phosphatases. Curr Opin Cell Biol 18: 185-191, 2006.

11. Kristjansdottir K and Rudolph J: Cdc25 phosphatases and cancer. Chem Biol 11: 1043-1051, 2004

12. Milligan B, Saville B and Swan JM: New syntheses of trisulphides. J Chem Soc pp4850-4853, 1961.

13. Derbesy G and Harpp DN: A simple method to prepare unsymmetrical di- tri- and tetrasulfides. Tetrahed Lett 35: 5381-5384, 1994.

14. Whelan RD, Waring CJ, Wolf CR, Hayes JD, Hosking LK and Hill BT: Over-expression of P-glycoprotein and glutathione S-transferase pi in MCF-7 cells selected for vincristine resistance in vitro. Int J Cancer 52: 241-246, 1992.

15. Mosmann T: Rapid colorimetric assay for cellular growth and survival: application to proliferation and cytotoxicity assays. J Immunol Methods 65: 55-63, 1983.

16. Osbild S, Brault L, Battaglia E and Bagrel D: Resistance to cisplatin and adriamycin is associated with the inhibition of glutathione efflux in MCF-7-derived cells. Anticancer Res 26: 3595-3600, 2006 
17. Brault L, Denancé M, Banaszak E, El Maadidi S, Battaglia E, Bagrel D and Samadi M: Synthesis and biological evaluation of dialkylsubstituted maleic anhydrides as novel inhibitors of Cdc25 dual specificity phosphatases. Eur J Med Chem 42: 243-247, 2007.

18. Brezak MC, Quaranta M, Mondésert $\mathrm{O}$, Galcera MO, Lavergne O, Alby F, Cazales M, Baldin V, Thurieau C, Harnett J, Lanco C, Kasprzyk PG, Prevost GP and Ducommun B: A novel synthetic inhibitor of CDC25 phosphatases: BN82002. Cancer Res 64: 3320-3325, 2004.

19. Maul A: Application of generalized linear models to the analysis of toxicity tests data. Environ Monit Assess 23: 153 $163,1992$.

20. Brault L and Bagrel D: Activity of novel Cdc25 inhibitors and preliminary evaluation of their potentiation of chemotherapeutic drugs in human breast cancer cells. Life Sci 82: 315323, 2008

21. Brezak MC, Quaranta M, Contour-Galcera MO, Lavergne O, Mondesert O, Auvray P, Kasprzyk PG, Prevost GP and Ducommun B: Inhibition of human tumor cell growth in vivo by an orally bioavailable inhibitor of $\mathrm{CDC} 25$ phosphatases. Mol Cancer Ther 4: 1378-1387, 2005.

22. Scherer C, Jacob C, Dicato M and Diederich M: Potential role of organic sulfur compounds from Allium species in cancer prevention and therapy. Phytochem Rev 8: 349-348, 2009.

23. Nakagawa H, Tsuta K, Kiuchi K, Senzaki H, Tanaka K, Hioki K and Tsubura A: Growth inhibitory effects of diallyl disulfide on human breast cancer cell lines. Carcinogenesis 22: 891-897, 2001.

24. Cerella C, Scherer C, Cristofanon S, Henry E, Anwar A, Busch C, Montenarh M, Dicato M, Jacob C and Diederich M: Cell cycle arrest in early mitosis and induction of caspase-dependent apoptosis in U937 cells by diallyltetrasulfide (A12S4). Apoptosis 14: 641-654, 2009.
25. Hosono T, Fukao T, Ogihara J, Ito Y, Shiba H, Seki T and Ariga T: Diallyl trisulfide suppresses the proliferation and induces apoptosis of human colon cancer cells through oxidative modification of beta-tubulin. J Biol Chem 280: 41487-41493, 2005.

26. Xiao D, Zeng Y, Hahm ER, Kim YA, Ramalingam S and Singh SV: Diallyl trisulfide selectively causes Bax- and Bakmediated apoptosis in human lung cancer cells. Environ Mol Mutagen 50: 201-212, 2009.

27. Druesne N, Pagniez A, Mayeur C, Thomas M, Cherbuy C, Duée PH, Martel P and Chaumontet C: Diallyl disulfide (DADS) increases histone acetylation and p21 (waf1/cip1) expression in human colon tumor cell lines. Carcinogenesis 25: 1227-1236, 2004.

28. Wu CC, Chung JG, Tsai SJ, Yang JH and Sheen LY: Differential effects of allyl sulfides from garlic essential oil on cell cycle regulation in human liver tumor cells. Food Chem Toxicol 42: 1937-1947, 2004

29. Anwar A, Burkholz T, Scherer C, Abbas M, Lehr CM, Diederich $\mathrm{M}$ and Jacob C: Naturally occurring reactive sulfur species, their activity against Caco-2 cells, and possible modes of biochemical action. J Sulfur Chem 208: 251-268, 2008.

30. Herman-Antosiewicz A and Singh SV: Checkpoint kinase 1 regulates diallyl trisulfide-induced mitotic arrest in human prostate cancer cells. J Biol Chem 280: 28519-28528, 2005.

31. Filomeni G, Aquilano K, Rotilio G and Ciriolo MR: Glutathionerelated systems and modulation of extracellular signal-regulated kinases are involved in the resistance of AGS adenocarcinoma gastric cells to diallyl disulfide-induced apoptosis. Cancer Res 65: 11735-11742, 2005.

32. Rudolph J: Cdc25 phosphatases: structure, specificity, and mechanism. Biochemistry 46: 3595-3604, 2007.

33. Rudolph J: Redox regulation of the Cdc 25 phosphatases Antioxid Redox Signal 7: 761-767, 2005. 